\title{
Experiential Marketing and Marketing Performance of Alcoholic and Non-Alcoholic Beverages in Nigerian Breweries PLC
}

\author{
Henry N. Ozuru, Akahome Joy E. \\ University of Port-Harcourt, Nigeria \\ Federal University Otuoke, Bayelsa State, Nigeria \\ Oscap2013@yahoo.co.uk, joyakahome@yahoo.com, akahomejj@fuotuoke.edu.ng
}

\begin{abstract}
This paper provided a theoretical review on how Nigerian Breweries uses its range of products to influence customer buying decision. This study examines the benefit of customer engagement and helps to understand the role of emotional benefit on marketing performance of beverages in the Nigerian Breweries plc. Experiential marketing play an important role in the industrial sector of a country, but faced with lots of constraints that impede its development and growth. These constraints include execution and also having creative ideas. How can a marketer generate interesting ideas that would help to pull sales for the brand? And how much cost should be incurred to project a huge life time customer experience in other to generate sales for a brand over a short time. This has led to inconsistencies in the continuation of events or shows by the company. The trend of experiential marketing is growing tremendously. The primary reason behind this is the exceptional procedures used by these services to allow one get focus from customer base and build relationship with them. Experiential marketing campaign is practically done anywhere. Therefore, previous studies suggest that most organizations did not take experiential marketing as an essential part of their marketing communication strategy; But with the change in communication process away from one way communication to two way communication and brands wanting immediate feedbacks for communication efforts, experiential marketing has now become a critical component of marketing efforts. We recommend that effective and efficient experiential marketing should be employed as a strategy to enhance marketing performance.
\end{abstract}

Keywords: Experiential Marketing, Marketing Performance, Nigerian Breweries, Consumer Behaviour, Engagement

\section{Introduction}

Nigerian Breweries Plc engages in the brewing and marketing of Lager beer, Stout and non-alcoholic malt drinks and the bottling of the Schweppes range of Soft drinks and Crush orange. The company's product range includes Star, Gulder, Legend Extra Stout, Maltina and Malta. These products are mainly sold in Nigeria and other neighboring countries (Bloomberg Markets, 2016). Therefore, previous studies suggest that most organizations did not take experiential marketing as an essential part of their marketing communication strategy; But with the change in communication process away from one way communication to two way communication and brands wanting immediate feedbacks for communication efforts, experiential marketing has now become a critical component of marketing efforts (Salau, 2015). Company brands do not only want consumers to see their products; they want them to feel it. This is why they often deploy the best creativity in any outing. Besides taking the game to meet people in their domain, the content not only appeals to the specific audience, it is usually carried out in a fun-filled, memorable encounter (Salau, 2015). Experiences are considered to be key concepts in marketing today. Experience is the key element in understanding consumer behavior and experience is the main component of experiential marketing. Brands are usually looking for new avenue to bond with consumers. This is why many organizations are deploying different experiential marketing effort.

The Marketing Director, Walter Drenth said "over the years, Star Lager Beer has risen to become the number one favorite beer and the undisputed market leader in Nigeria. The brand has continued to keep its consumers actively engaged all year round through exciting consumer engagement platform that cut through music, football and consumer promotions (Alonge, 2013). A lot of organizations do these by introducing a lot of television game shows that are associated with a product. For example, Nigeria breweries have introduced Star quest, Star mega jam, and Star music trek, it recently introduced "Star the winner is" Gulder Ultimate search, Maltina dance all (The Guardian newspaper). The reality TV show "star the winner is" has positioned the star brand as a strong pillar of entertainment in the country. Over the years, since the introduction of the 
"star brand", the promoters of "Star" have not ignored the fact that choosing or giving priority to entertainment is a major vehicle to position or promote the brand. Experiential marketing gives customers wide variety of experiences with products in order to give them the opportunity to have an emotional bond with the product in order to make purchase decision. Experiential marketing refers to the real experiences that consumers experience with the product to improve and increase sales. Experiential marketing connects with consumers through the participation and tangible nature of a personally relevant and memorable experience. Examples of experiential marketing that marketers engage in include special events, concerts, free samples, and touring exhibitions to promote a product or brand (Adweek, 2009). Through experiences such as these, experiential marketing provides an alternative form of marketing that allows consumers to directly sample what companies are offering by minimizing the detachment between consumers and companies.

Until Star Larger Beer from the stable of Nigerian Breweries entered the beer market over six decades ago, the market was being controlled by foreign brands. With the development, handlers of the foreign brands had to readjust and change their approach of addressing competitions. Few years after the launch of Star, it became obvious to stakeholders that the new comer was not a pretender. As a result of this, other local investors saw the market as an area that could still be tapped, hence the influx of many brands after the launch of Star. For Nigerian Breweries, the reality in the industry was considered as another opportunity to further explored the market and so it extended its frontier by introducing Gulder. From day one, Gulder has remained a newsmaker for obvious reason; its unique bottle, which its promoters thought would be an instant success, was rebuffed in some quarters. Those who believe beer must be in green bottle didn't appreciate the package of the new offering. But like all unique things, the bottle won for the brand appreciative followers. For these reasons, its story was full of different shades but the flag has since the beginning remained flying, despite the odds. It has become the game changer that is prompting agency owners to consider setting up an experiential marketing agency within their group to stay in business. While clients are slicing marketing budgets in relation to other promotional mix, experiential marketing agencies are feeding fat, though delivering on return-on-investments. As a result, these have heat up debate on the role of experiential marketing to sustain brand recall and influence purchasing decision.

Salau (2014) "Experiential marketing is a form of advertising that focuses primarily on helping consumers experiences a brand. While traditional advertising (radio, print, television) verbally and visually communicates the brand and product benefits, experiential marketing tries to immerse the consumers within the product by engaging as many other human senses as possible. In this way, experiential marketing can encompass other marketing strategies from individual sampling to large-scale guerrilla marketing." With the power of the emerging promotional mix to win consumers via exploring entertainment among other activities that engages consumers higher than traditional promotional mix, the marketing communication industry has massive use of the promotional mix to gain consumers attention. Recently, Nigerian Brewery launched an experiential campaign to engage their brand with consumers via, Black Revolution. The experiential campaign was meant to activate the new bottle for its stout brand, Legend Extra Stout but the use of Black Revolution as the experiential campaign, which was designed by Oracle Experience, an experiential marketing agency, the Black Revolution, explored Live Show with notable celebrities, such as Femi Anikulapo, Tuface Idibia, and Comedian Gordons, to thrill the audience. The agency used the short documentary to highlight the Legend brand to remind the target market, which was represented by selected audience at the Bar Beach, where the activation was done, to stay connected with the brand using all celebrities, the theatre and the campaign headline, Black Revolution, as the experience. The "Black Revolution" is presented as a movement that yearns for consumers in terms of satisfaction and quality. The trend of experiential marketing is growing tremendously and the primary reason behind this is the exceptional procedures used by these services to allow you to get focus from customer base. You will discover experiential branding campaigns practically anywhere. These services can help you build up a relationship with your customer base. Creating new experience is vital in the success of Nigerian Breweries.

Statement of Problem: Experiential marketing involves large amount of financial investments. A company's success requires large finance to be competitive in the industry but with low finance most firms especially the new ones may not survive and such tend to withdraw. Some suggest that television shows are experiential branding and depends on how you interpret it. So it's not about big budgets. It's about execution and also 
having creative ideas. How can a marketer generate interesting ideas that would help to pull sales for the brand? And how much cost should be incurred to project a huge life time customer experience in other to generate sales for a brand over a short time. Also, to what extent can experiential marketing be developed to improve sales, increase profit and improve the business growth?

Objective of study: The main objective of the study is to determine the influence of experiential marketing on marketing performance of Beverages in Nigerian Breweries Plc.

- To examine the benefit of customer engagement on the marketing performance of Beverages in Nigerian Breweries Plc

- To understand the role of emotional benefit on the marketing performance of Nigerian Breweries Plc

- To analyze the practice of brand loyalty on the marketing performance of Nigerian Breweries Plc

\section{Literature Review}

Theoretical foundations: Schmitt (1999a) focuses on those aspects of marketing aimed at creating experiences for customers and promises to provide "tools for this new approach". Schmitt (1999b) distinguishes five different types of experiences that marketers can create for customers. These experiences, called strategic experiential modules (SEMs), are implemented through so-called experience providers (ExPros), such as communications, visual and verbal identity, product presence, electronic media, etc. According to Schmitt (1999a), the framework of experiential marketing has two aspects: SEMs, which form the strategic underpinning of experiential marketing, and ExPros, which are the tactical tools of experiential marketing. Holbrook (2000) criticizes Schmitt saying that he arrays the SEMs and ExPros against each other to form a conceptually useful experiential grid, though it presses credulity a bit when Schmitt positions this rather modest conceptual framework as "a key strategic planning tool of experiential marketing". The author of this paper stresses that marketing planning tool is tactical, not strategic. The whole experience marketing methodology is based on experiences, not specific activities that are experiential in nature.

Carù \& Cova (2003) are also critical towards Schmitt and in general towards American romanticism (authors Holbrook, Schmitt, Pine, Gilmore etc). They confirm that this allowed Holbrook (1997) to propose the logical sequence: 'romanticism $\rightarrow$ experiential consumption $\rightarrow$ emotional responses $\rightarrow$ pleasure', and to insist on the fact that in this experiential approach, sensations are more important than the consumers' rational thoughts. Schmitt (1999b) extends the traditional features-and-benefits paradigm to build a conceptual model for designing, managing, and integrating consumption-based experiences (Holbrook 2000). The author of this paper emphasizes that Schmitt's toolkit is not strategic marketing management, but it focuses on tactical and operational level actions where the main question is how to do marketing campaigns experientially. Of course the operational level is a vital link between tactics and strategy. Experiential marketing allows customers to engage and interact with brands, products, and services in sensory ways that provide the "icing on the cake of providing information". Hauser (2011) says that the term 'experiential marketing' refers to actual customer experiences with the brand, product or service that drive sales and increase brand image and awareness.

Snakers \& Zajdman (2010) define experiential marketing as a new way by making the customers to live an experience through the creation of emotions. Thus, experiential marketing has a goal to create emotions to the customers that lead to enjoying the experience. You-Ming (2010) suggests that experiential marketing is a kind of face-to-face communication method, which mainly raises customers' physical and emotional feelings so that customers expect to be relevant and interactive to some brands and to feel and experience wholehearted. The author of this paper highlights that all these definitions indicate that experiential marketing is mainly and directly related to emotions, feelings, and senses and has less to do with cognitions and human intentions. Cantone \& Risitano (2011) confirm that in the last years, many firms are adopting CEM strategies in which are emphasized the role of emotions, feelings, sentiments, passions and experiences in the consumer-brand relationships“. According to Yuan \& Wu (2008) experiential marketing can be seen as a marketing tactic designed by a business to stage the entire physical environment and the operational processes for its customers to experience.

What is then experiential marketing? When we ask ten different people to define experiential marketing, we will probably end up with ten different answers. Meier (2010) points out that Hauser commented in 2007 
that the "definition of experiential marketing is fluid - as is the methodology itself. It was once little talked about, and is now being embraced as a silver bullet". Hauser once posed the simple question of experiential marketing's definition to the Experiential Marketing Forum, and received more than 200 definitions from more than 150 countries (Ibid.). When Schmitt (1999a) explains the idea of Pine and Gilmore's experience economy he uses the phrase 'experiential economy'. It shows how those terms and words are used interchangeably. Smilansky (2009) says that experiential marketing is the process of identifying and satisfying customer needs and aspirations profitably, engaging them through two-way communications that bring brand personalities to life and add value to the target audience. International Experiential Marketing Association (2011) declares that experiential marketing can be seen as a marketing tactic designed by a business to stage the entire physical environment and the operational processes for its customers to experience. Hekkert (2006) distinguishes three levels of experience: attribution of meaning (experience of meaning), emotional response (emotional experience), and aesthetic pleasure (aesthetic experience). These experiences influence value co-creation, purchase decisions and behavior

Experiential Marketing and Customer's Satisfaction: However, the use of experiential marketing as a communication method is growing fast and companies believe it can provide them competitive advantages compare to that of traditional marketing/communication. Consumer behaviour is premised on personal experience and others opinion. Therefore, companies like Nigerian Breweries should endeavour to develop new memorable experience that will appeal to consumers. Nigerian breweries have been around for years sharing different experiences through the brands of alcoholic beverages and non-alcoholic beverages. Maltina is one of the non-alcoholic malt drink sponsored by the company. It organized a show called Maltina Dance All (MDA) to showcase togetherness among families and friends where they compete for a price at the end of the show. It is a foremost experiential and sponsorship platform of the Maltina brand renowned for promoting togetherness with friends and loved ones. The TV show, which made debut in 2007, has remained Nigeria's first and only family dance TV show featuring families from various regions across the country (NBPlc, 2011). The show is about the emotions, excitement, fun and the unbreakable bond that ten families will showcase when they challenge themselves by learning and performing various dance styles in the famous Maltina dance All Academy. The show which is seen by sharing happiness, the MDA is the consumer engagement platform that the brand uses to resonate with esteemed customers and the society in general. Star premium beer is Nigeria's leading beer has announced the kickoff of a new football game show. The first of its kind will be an engrossing campaign that will test the passion, knowledge and skills of football fans and provide platform to be seen and celebrated. (Nigerian Breweries Plc, 2016) 'Star is a brand known for always rewarding its loyal customers and this game show is another way to do so. It's been music for a while but this time, we bring football to the table because they understand that football fans are everywhere in Nigeria. According to (NBPlc, 2016) this is another of 'Stars numerous platforms to reward consumers loyalty and amplify their passion following the success of STAR Trek, STAR Quest and most recently STAR The winner is.

\section{Conclusion}

Experiential marketing captures the imagination of marketers and brands across nation. In this regard, effective brand can reach and engage consumers based on emotional and rational level in a way old media methods never could. Marketers need to understand the importance of experience marketing because experience in marketing as it is one of ways to gain competitive advantage in a competitive business environment.

Recommendations: We recommend that effective and efficient experiential marketing should be employed as a strategy to enhance marketing performance.

\section{References}

Alonge, O. (2013). Star league-Text and Play Kicks off this April. Thenet.ng Posted on April 04.

Adweek (2009). Entrepreneur magazine; Emerald Insight; Proceedings of the 41st Hawaii International Conference on System Sciences (2008) Copyright 2011Little\& King Integrated Marketing Group, Inc.

Bloomberg Markets. (2016). Nigerian Breweries: Lagos stock Quote - Nigerian Breweries PLC-Bloomberg Markets.www.bloomberg.com>quote>NB: NL 
Cantone, L. \& Risitano, M. (2011). Building consumer-brand relationships for the customer experience management, in The 10th International Marketing Trend Conference. Paris, France, 20-22 January 2011. Selected papers. Paris, 2011, 1-33. ISBN 978-2-9532811-2-5.

Carù, A. \& Cova, B. (2003). Revisiting Consumption Experience. Marketing Theory, 3(2), 267-286.

Hauser, E. (2011). Experiential Marketing Forum (accessed August 7, 2011), [available at http://www.experientialforum.com]

Hekkert, P. (2006). Design aesthetics: Principles of pleasure in product design. Psychology Science, 48(2), 157-172.

Holbrook, M. B. (1997). Romanticism, Introspection and the Roots of Experiential Consumption: Morris the Epicurean, Consumption. Market and culture, 1(2), 97-164.

Holbrook, M. B. (2000). The Millennial Consumer in the Texts of Our Times: Experience and Entertainment. Journal of Macro marketing, 20(2), 178-192.

International Experiential Marketing Association. (2011). Available from Internet: http://www.experientialforum.com

Meier, D. (2010). Reading List Challenge: 19 Experiential Marketing Books (accessed August 18, 2011), [available at http://www.javelinexperiential.com/experiential-marketing /reading-list-challenge-19experiential-marketing-books]

Nigerian Breweries Plc. (2016). Star Debuts New Football TV Game Show, Star Football Superfans April 9th 2015.

The Guardian Newspaper. (2015). Forecasting breakthrough for experiential marketing in 2015 by Gbenga Salau. 18 January 2015.

The Guardian Newspaper. (2014). Nigeria: Raising the stakes in experiential marketing by Gbenga Salau, 27 October 2014.

The Guardian Newspaper. (2014). Nigeria: reaching out through experiential marketing by Gbenga Salau. 22 September 2014

Schmitt, B. (1999a). Experiential marketing: How to get customers to sense, feel, think, act and relate to your company and brands The Free Press, New York, USA.

Schmitt, B. (1999b). Experiential Marketing. Journal of Marketing Management, 15(1-3), 53-67. http://dx.doi.org/10.1362/026725799784870496

Smilansky, S (2009). Experiential Marketing: A Practical Guide to Interactive Brand Experiences Kogan Page, London, UK

Snakers, E. \& Zajdman, E. (2010). Does experiential marketing affect the behavior of luxury goods' consumers? Umeå: Umeå Universitet

You-Ming, C. (2010). Study on the Impacts of Experiential Marketing and Customers' Satisfaction Based on Relationship Quality. International Journal of Organizational Innovation, 3(1), 189-209.

Yuan, Y. H. \& Wu, C. (2008). Relationship among Experiential Marketing, Experiential Value, and Customer Satisfaction. Journal of Hospitality and Tourism Research, 32(3), 387-410. 